\title{
How to silence the lambs? \\ Article Constructing authoritarian governance in post-transitional Hungary
}

\section{Veronika Nagy}

Willem Pompe Institute for Criminal Law and Criminology, Utrecht University, The Netherlands.

v.nagy@uu.nl

\begin{abstract}
This paper examines a range of arguments put forward to explain how financial surveillance of non-governmental organisations empowers authoritarianism in the post-transitional Hungarian context. In doing so, it attempts to shed light on the limitations of existing surveillance theories regarding the historical component of surveillance tolerance and the different modes of governance in post-communist European countries. It argues that post-transitional disappointment in democratic governance is causing Hungarians to become resigned to political decisions and to support new forms of authoritarian rules. Such a stoic attitude and the historically embedded surveillance culture facilitate the use of monitoring mechanisms that not only target terrorists as an external security threat, but also target NGOs defined as 'the enemies of national values'. Hungarian authoritarian policies are not facilitated by extended surveillance practices, as Anglo-Saxon theories have regularly argued, but by the way they are used as an instrument of a political deterrence strategy against political opponents.
\end{abstract}

\section{Introduction}

'I think that to accuse a country and a governing party like ours of running some sort of authoritarian regime, to mention this in relation to us, is simply unjust and unfair', stated Viktor Orbán, Hungary's Prime Minister, in his speech to the European Parliament in Brussels on 26 April 2017. He continued: 'We have had enough of this thinking. We believe there can still be democracy even if the liberals do not win. Illiberal democracy is when someone other than the liberals have won' (Website of the Hungarian Government 2017).

This heated debate at the European Parliament in 2017 is only one example of how the Hungarian government and its political leadership appear on the front pages of international newspapers: described as the threatening example of growing authoritarian regimes in the heart of the European Union.

Although many EU member states implement illiberal policies (e.g. extended digital surveillance measures) under the flag of terrorist threat, these serve different modes of governance in post-transitional member states. Based on the new surveillance strategies as a mode of governance, I will argue that the latest Hungarian authoritarian policies are not supported by extended surveillance practices, as Anglo-Saxon theories have regularly argued, but by the way they are used as instruments of a political deterrence strategy against political opponents. This contextually specific process can be explained by two key differences between Hungary and established democratic governments. On the one hand, a structural lack of human

Nagy, Veronika. 2017. How to silence the lambs?-Constructing authoritarian governance in posttransitional Hungary. Surveillance \& Society 15(3/4): 447-455. 
rights protection and privacy arises from the constraints of a post-communist society. This condition explains social acceptance of mass surveillance and distrust. On the other hand, the Hungarian government justifies newly introduced monitoring practices in terms of cultural and economic threats from Western incentives that are associated with neoliberal values. This justification increases support from the Hungarian majority, who are disappointed in the results of the democratic transition. The justification of targeted surveillance strategies is thus framed as a measure to protect Hungarian culture and the national political independence as distinct from EU principles.

I will argue that post-transitional disappointment in democratic governance has caused Hungarians to become resigned to political decisions and to support new forms of authoritarian rules. Such a stoic attitude and the previously historically embedded surveillance culture facilitates the use of monitoring mechanisms that not only target migrants as an external security threat, but also target non-governmental organisations (NGOs) that are defined as 'the enemies of national values'.

First, I will introduce contextual concerns from surveillance theories and describe how these should be embedded as a mode of authoritarian governance in a neoliberal post-transitional society. Second, I will analyse recent changes in the Hungarian political environment to explain how institutional shifts created the recent surveillance state. Third, I will present cases of authoritarian governance strategies, in particular surveillance power used to eliminate non-governmental stakeholders by financial monitoring/criminalisation. As I will argue, surveillance dissuades members of civil society from political activism or protest by threatening them with financial repression and existential deprivation. Finally, I will present my conclusions.

\section{A theoretical gap or the cultural legacy of surveillance}

As critical surveillance scholars have argued, the power in surveillance is far greater than systematic observation and data collection. Based on Foucault's concept of a 'disciplinary society', Lyon developed the concept of a technology-based 'surveillance society', where governmental and privatised security services cooperate to 'discipline the masses' (Green 1999: 29). According to theories like the liquid surveillance theory, the way that surveillance functions in neoliberal democracies or 'advanced societies' is that more individualised solutions are generated while surveillance becomes simultaneously less visible. Also, based on these concepts, sophisticated technical tools extend existing surveillance practices with electronic databases, enabling the creation of a new digital 'bureaucracy' in favour of 'national security' and 'commercial competition' (Bauman 2013; Lyon 2003). However, this approach does not include the contextual differences of post-communist versus historically democratic regimes and the surveillance role of civil society.

In short, Surveillance Studies has been understood to depart from within the framework of the (neo)liberal capitalist democracy (Lyon 2010: 325). To understand how post-transitional societies are able to facilitate authoritarian governance through surveillance mechanisms, I will present several aspects of this paradigm. A report issued by the SURVEILLE project argues that:

Surveillance powers are used in authoritarian ways when they are unconstrained or insufficiently constrained by checks and balances of rule of law, impartiality, transparency and accountability: secret surveillance, surveillance outside a legal framework, surveillance that is subject to poor oversight, and surveillance whose proportionality cannot be effectively contested by individuals are all examples. When surveillance powers are used in authoritarian ways, people are exposed to rights-violations resulting from the corrupt, disproportionate, discriminatory uses that result from a lack of rule of law and democratic constraints. Illiberal purposes to which surveillance powers might be applied include the silencing of political dissent, the pursuit of personal or party interests and the restriction of 
rights in order to impose ideological orthodoxies amongst other things'. (Hadjimatheou 2013)

These powers have a strong contextual determination that differs from established democratic states. Van der Burg (1991) argues that there are several levels to the extent to which surveillance may remove barriers to authoritarian government. Some slippery slope arguments treat all kinds of surveillance techniques as cumulatively responsible for driving us down the slope (Kateb 2001), making people more tolerant of authoritarian uses of state power and encouraging governments to see and treat people as mere conscripts to their purposes, denying their autonomy and therefore allowing them to be used for illiberal ends. As I will present through the selected cases, these slippery slope arguments in Hungary are deeply embedded in the post-communist experiences of the past, creating different opportunities to discipline the society in authoritarian terms.

\section{Post-transitional political context}

Surveillance as a mode of governance resides on a historical process of justification, in which the legitimation of control is framed in terms of security and threat. Democratic governments use institutional means to justify and administer their movement towards a system of increasing authoritarianism. This 'paradigm of fear and domination' has become a depoliticised expert administration of nation states, where governments increasingly operate outside of their direct democratic mandate. This is symbolic of the coordination of ideologically driven interests (Žižek 2010). Though there is a similar paradigm in posttransitional societies, surveillance strategies are rarely differentiated based on their ideological interests. Formerly authoritarian and/or totalitarian societies that were ruled by a communist regime, such as Hungary, conceptualise surveillance measures and government transparency from a different cultural legacy than societies with democratic roots.

Political scientists have studied the plastic democracy-authoritarian dimension for many years, developing concepts such as 'hybrid regimes', 'competitive authoritarianism', 'semi-democracy' and 'transition democracies' (Ekman 2009; Levitsky and Way 2010). They are all ways of denoting the failure of transformation in all but the most Western societies in Central and Eastern Europe. This difference is important from a surveillance-theoretical perspective because it means that the much-adored dichotomy between liberty and security is not so central when everyone knows that both are negotiable. Liberty may be a distant goal to strive for and security an ambivalent goal that may very well be easier to reach in a 'strong leader' system (Ekman 2009).

Since the Hungarian government won a two-thirds majority in the unicameral parliament, the governing party has made several legislative changes that fulfil the preconditions of a surveillance state, and have eliminated or repressed all those democratic platforms that would challenge control and surveillance practices. In only three years - from 2010 to 2013 - the government managed to transform Hungary from a success story about the transition from socialism to democracy to a semi-authoritarian regime based on an illiberal constitutional order that is systematically dismantling checks and balances and thereby undermining the rule of law. The novelty and irony of the Hungarian slide into authoritarianism is that it was achieved entirely through legal means. In particular, the Fidesz government has accomplished a fundamental revision of the rules of the constitutional and political order in Hungary and redesigned bureaucratic power accordingly.

Hungary thus represents a politically distinctive case of authoritarianism. Generally, authoritarian leaders usually undermine democratic institutions by not respecting the rule of law, while Hungary has managed to undermine the rule of law by changing legal rules, i.e. the constitution. Such a 'constitutional revolution' thus produced a nominally 
democratic constitution, which, as Bánkuti, Halmai and Scheppele argue, 'can no longer be described substantively as a republican state governed by the rule of law'. (Bugaric 2015)

After the legislative shifts, the government immediately imposed surveillance measures. As a heritage from the political infrastructure of previous regimes, the public administration has reduced discretionary space in decision making and is closely linked to political power. As part of that cultural legacy, present Hungarian administrative staff accept all their instructions from above, even if they know that they are of low quality. This has resulted in a drastic decrease in the professionalisation and social prestige of the Hungarian administrative elite (Tavares Report 2013). Increasing overlaps between politics and public administration and the amalgamated tasks of different governmental organs (police, the National Tax and Customs Administration, the Counter Terrorism Centre, local authorities) have led to a reduction in government quality. With such a repressive bureaucratic power threatening those who might criticise governance strategies, no one is willing and able to hold the government to account (Hadjimatheou 2013).

As a result, the over-politicisation of the administrative elite has worsened their social status, professional training and career management. The permanent rotation has also undermined the administrative elites' long-term social positions. Their career prospects have become very volatile since closed political patronage is now the dominant trend of political appointments in career management. These new recruits are different from the old guard, being both young political entrepreneurs and emerging policy technocrats. Erected on the post-transitional disappointment in the Hungarian society, this new power structure with its administrative elite might raise its power and employ new authorial strategies without showing any resistance against illiberal measures on administrative level.

In short, 'cultural legacy' should be problematised as a historical variable that denotes the transcendence of collective experience to form frames for interpretation that are detached from their original context. As I will discuss, in a post-transitional country such as Hungary, the road to an authoritarian government cannot only be built on radical limitations of democratic governance practices, but also by public support and constant existential threat from those who might contest this authoritarian power.

It is not only the public administration that is silenced, but civil society as well; they are paralysed by the soft authoritarian surveillance state. In the following analyses, I will present recent governance strategies for surveillance of those stakeholders working on human rights protection issues. By stressing the role of financial surveillance in authoritarian governance strategies, I will critically analyse the cultural justification of such practices in a post-communist society.

\section{The new culture of pre-policing in Hungary}

The decline, or slippery slope, from democratic to authoritarian governance can be explained by the asymmetric surveillance power between the state and its citizens (Fuchs 2012; Lyon 2010; Dubbeld 2003). Surveillance strategies are the distinctive tools of governance in this process (Lyon 2007:15). The proliferation of surveillance techniques introduces and exacerbates such asymmetries, disempowering individuals while simultaneously strengthening the hand of the state and opening the door to authoritarianism. Surveillance can be said to increase two kinds of state power: the power to enforce the law and the power to intrude into individuals' private lives and interfere with data about them. The latter kind of power reinforces the former: the greater the power to intrude into privacy and collect and process data, the greater the power to enforce the law (Hadjimatheou 2013). In recent decades, several data surveillance measures have been legitimised in Hungary that eliminate the role of data protection and entitle different parties in the public administration system to intrude into privacy. As I will argue, these measures were not only created for crime prevention, but also to profile and threaten political opponents as representatives of civil society who challenge the use of authoritarian surveillance measures. 
The 2006 Data Retention Directive requires all the telecommunication service providers in Hungary to collect and store metadata which shows who, when, where and with whom anyone tried to or successfully communicated with via email or phone. This was the first step backwards in the protection of privacy in Hungarian legislation, since it gave a vague description of surveillance limitations. The text of the directive was not clear about storing the content of the data and did not mention the necessity of judicial authorisation, court oversight or any external supervisory mechanism. It also forgot to prescribe the obligation to inform the person under surveillance concerned about the use of his/her data and to destroy the data after the end of legal proceedings. Finally, there was nothing about who guards the guardians: who inspects or monitors the process of destroying the data when the retention time is over. Possibly the worst thing of all was that the authorities were granted direct access to the telecommunication service providers' data rooms. The modification of the National Security Law on 24 May 2013 expanded these legitimised practices to include the surveillance of high-level public officials.

Since the law was designed to allow the state to identify any risks that could lead to someone influencing or blackmailing a person under surveillance, which would in turn cause state security issues, Hungary's ombudsman for basic rights, Mate Szabo, initiated a constitutional review. He raised concerns about a lack of external control over the monitoring process and the fact that agencies would not be required to provide a concrete reason or aim for the monitoring activity, which would give the state an unfair power advantage over the individual targeted in the surveillance. Despite the protests, the amendment was enforced on 1 August 2013. ${ }^{1}$

A similar case is that of the Anti-Terrorism Task Force, which was established within the police force from 1 January 2011. Its duties were defined in section 7/E of Act no. XXXIV of 1994 on the Police, as amended by Act no. CCVII of 2011. Under this legislation, the task force's prerogatives in the field of secret intelligence gathering include secret house searches and surveillance with recording, opening letters and parcels, as well as checking and recording the contents of electronic or computerised communications. All of this without the consent of the persons concerned. ${ }^{2}$

Also in 2011, Hungary appeared on the list of those countries that used FinFisher, the infamous government spy software package that gives access to all data on an infected computer, including emails, documents and voice over internet protocol calls. There were few reactions in Hungary when this news was published, but Transparent International submitted a public information request about the extent of the software use to the Constitution Protection Office on 17 October 2013 (Atlatszo.hu 2014). The request was refused based on national security interests. It is this increased power to gather knowledge that poses a threat to liberal democracy, because it can potentially be directed to purposes other than law enforcement (Lyon 2007, 2010). These data retention practices lead to extreme data collection from non-governmental media representatives, radio stations and NGOs whose members have been personally listed and accused of fraud or unpatriotic activism, and threatened with penal measures. These sorting and profiling strategies are

\footnotetext{
${ }^{1}$ Though the Court of Justice of the EU (CJEU) suspended the Directive in 2014, a new parliament set up in late May did not follow the court's decision, meaning that the amendment stood.

2 In Szabó and Vissy v. Hungary (application no. 37138/14), the European Court of Human Rights unanimously held that there had been a violation of Article 8 (right to respect for private and family life, the home and correspondence) of the European Convention on Human Rights, and no violation of Article 13 (right to an effective remedy) of the European Convention. The case concerned Hungarian legislation on secret anti-terrorist surveillance introduced in 2011. The Court accepted that it was a natural consequence of the forms taken by present-day terrorism that governments resort to cutting-edge technologies, including massive monitoring of communications, to pre-empt impending incidents. However, the Court was not convinced that the legislation in question provided sufficient safeguards to avoid abuse. See more: http://www.statewatch.org/news/2016/jan/echr-case-SZAB-\%20AND-VISSYv-\%20HUNGARY.pdf
} 
justified in a nationalist cultural media discourse in which foreign-funded activism is a symbol of 'disloyalty towards Hungarian society'.

Governments use surveillance powers in authoritarian ways when they are unconstrained or insufficiently constrained by checks and balances of rule of law, impartiality, transparency and accountability. Examples include secret surveillance, surveillance outside a legal framework, and surveillance whose proportionality cannot be effectively contested by individuals. When governments use surveillance powers in authoritarian ways, people are exposed to rights violations resulting from the corrupt, disproportionate and discriminatory uses that result from a lack of rule of law and democratic constraints. Surveillance powers might be applied to illiberal purposes, such as silencing political dissent, pursuing personal or party interests, or restricting rights to impose ideological orthodoxies.

Although the changes mentioned above are clear examples of these incentives, the majority of Hungarians have not provided any significant negative response to them. These surveillance strategies are not only manifesting the impetus of the (ideological) systems and organisations of government security intelligence forces, but they are also features of a very historical process in their justification. The social-economic circumstances of current post-transitional societies in Central Europe-principled on a distinctly coercive structure - have eased systematic institutional methods of authoritarianism and subordination with regards to the civil rights and liberties of the social masses (Heathwood Institute and Press 2013). The present administration is justifying the establishment of the Hungarian Counter Terrorism Centre (TEK) as an organisation and its secretive, undemocratic operations as a state necessity because, in some respects, the very structure of our modern state of affairs seems inherently driven towards establishing the appropriate context for institutionally legitimising the systematic corrosion of civil rights and liberties. Therefore, new hybridised forms of authoritarian control are being developed under post-transitional capitalist pressure.

Bigo (2006) posits that:

Contemporary surveillance movements are growing globally, but effective controls and coercive restrictions of freedom are concentrated on specific targets. The normalisation of emergency and targeting have become the techniques of governing by unease, based on differentiation between a normalised population that is pleased to be monitored 'against danger' and an 'alienation' of some groups of people who are considered to be dangerous 'others'.

By individualising pathology through bureaucratic codification, risk is defined by individual characteristics and classified into risk categories of decision-makers (Lyon 2003). In short, power relations can be traced through the identification and classification of individuals into specific databases. Accordingly, in the posttransitional context where Hungarian society is disappointed by the failed implementation of democratic values, surveillance serves not as a governmental incentive in the Foucauldian sense-as a disciplinary power-but as a tool of populist deterrence against political opponents to establish authoritarian power justified by nationalist notions of cultural security. The following case illustrates this historically embedded situation.

\section{The crucifixion of civil society}

Giddens asserts that: 'Surveillance as the mobilizing of administrative power-through the storage and control of information - is the primary means of the concentration of authoritative resources involved in the formation of the nation-state' (1985: 181). By individualising pathology through bureaucratic codification, risk is defined by individual characteristics and classified into risk categories of decision-makers (Lyon 2003: 250). In the case of increasing authoritarian power, these categories are not defined in political terms, but often in terms of culture and criminality to justify more legitimacy for control and sanctions. This 
process can be traced in the constant targeting and sanctioning process of foreign-funded NGOs associated with political opposition to the Hungarian government.

To understand the role of surveillance as the mode of authoritarian governance, we need to reflect on the sorting and criminalisation mechanisms that are used against Hungarian civil society. Since the role of NGOs is, amongst others, to guard the democratic values and reflect on state governance practices, the government frames those NGOs who are not dependent on government funds and who cannot be controlled by financial restrictions in terms of threat, representing foreign political interests. Financial screening, house searches and personal intimidation of NGO workers has become the new mode of disciplinary power used to silence those who might challenge legislation on disproportionate surveillance measures.

On 23 May 2014, Prime Minister Orbán personally ordered the Government Control Office (GCO) 3 to take extraordinary government control of the expenditures, financial mechanisms and financial institutions of the Norwegian Civil Aid Fund (NCTA) in Hungary. Based on this ministry order, the GCO launched an investigation in 2014 that monitored 62 NGOs over a two-year term. These extended financial screenings were meant to suspend the tax identification numbers of four foundations at the National Tax and Customs Administration (Government Control Office 2015). This intrusive audit included a 16-month police investigation that also initiated house searches in which seven organisations were screened. These organisations were presented as a threat to the Hungarian rule of law and described as foreign-founded propaganda against the Hungarian government.

Ultimately, none of the NGOs' tax identification numbers were suspended. In one case, the court stated that the proceeding was unjustified and unlawful (The Budapest Beacon 2016). Meanwhile, government communication in the media has consistently referred to foreign protagonists with political interests as 'politically-funded civilians' and named organisations that did not have the role of law-defending tasks in place of government-entrusted civil service tasks. These organisations received their support from sources whose award and management is in the hands of independent political party organisations.

Although the government has attempted to include state control of NCTA's resources, it has failed. According to Howard, Carr and Milstein (2005), surveillance is political to the extent that the data can be used to infer a person's convictions and preferences as part of processes designed to influence, sanction or exclude. According to the Hungarian Civil Liberties Union, these audits were another step towards discouraging citizens from participating in public affairs and towards stamping out organisations that operate independently of government to serve foreign interests instead of community goals (Kateb 2001).

Similar cases happened with NGOs funded by George Soros. These types of existential threats limit 'sousveillance'; in other words, they threaten citizens who might monitor the government and powerful groups or who might use the media or judicial system to hold them accountable for abuses (Kohn 2010). Such blacklisting and financial targeting measures discourage citizens from using their legal right to expose corruption and other illegitimate uses of state power (Hadjimatheou 2013).

As these cases illustrate, these members of civil society experienced the intimidation and criminalisation effect of this 'old mode of governance' described as personal deterrence. Those blacklists echo the historical memories of the communist regime associated with fear of prosecution and existential harassment, or public

$3 \mathrm{GCO}$ is the government control body of the Hungarian government. It is governed by the minister responsible for the organisation of public administration. It is an autonomously managed central budgetary organisation with public authority and chapter rights, the budget of which forms a separate title in the chapter of the Ministry of Public Administration and Justice. Its heads and the order of their appointment are defined in Art. 63-67 of Act CXCV of 2011 on Public Finance and by Government Decree No. 355/2011 of 30 December 2011 on the Government Control Office. 
shaming. Due to Hungarians' collective experiences of surveillance in the past, recently increasing nationalist sentiments and EU scepticism, these intimidating surveillance strategies as a mode of governance have successfully threated those who were willing to step up to protest illiberal policies and advocate for privacy rights.

\section{Conclusion}

Hungarian surveillance measures are received by social inertia in a post-transitional political context. This apathy from Hungarian society and the targeting mechanisms against NGOs hinder citizens' ability to contest government agencies and control practices. In addition, surveillance policies are constructing barriers to transparency and accountability of surveillance strategies, as well as the use of ombudsmen and data protection authorities.

In contrast with authoritarian surveillance practices in Western states, Hungary established a cultural legacy of authoritarian governance that enables the slide from democratic to illiberal disciplinary rules. A heritage of social and political distrust has helped to create post-communist states where security problems are defined in terms of the oppressor and the intruder (Sapsford and Abbott 2006). The criminal insider in posttransitional states is not constructed in terms of relative deprivation or drift, but in terms of cultural difference, a lack of moral values or even unpatriotic behaviour. These post-transitional constructs are (ab)used and adapted by political narratives, associating civil society, foreign-funded NGOs and human rights activists with espionage, national corrosion and cultural loss. Framing political opponents in such terms justifies and legitimises new surveillance measures that target such groups-defined as political opponents - in terms of national protection.

These historically embedded justification strategies enable new democratic governments to use democratic tools for authoritarian purposes, and to implement surveillance and control measures against political opponents, or extend the level of data surveillance. Civil society and other political opponents also carry the post-communist fear of terrorism represented by illiberal governance, which makes them more sensitive to intimidation and financial sanctions than similar organisations in Western countries. Therefore, surveillance measures, threats of serious sanctions and criminalisation of NGO activities serve as deterrence strategies. By silencing these voices of political opposition, illiberal authoritarian measures enable more mass surveillance and political control. While Western surveillance justification processes are legitimised by the threat of extremism and terrorism, Hungarian post-transitional surveillance practices are legitimised by antiEU references, linking NGOs with Western cultural values and national betrayal. These notions not only feed EU scepticism and legitimise more government power, but also reinvent and conserve the authoritarian political strategies of the previous regime.

\section{References}

Atlatszo.hu. 2014. "Hungary exposed as user of FinFisher spy program." Last modified August $26,2014$. https://english.atlatszo.hu/2014/08/26/hungary-exposed-as-user-of-finfisher-spy-program/.

Bauman, Zygmunt. 2013. Liquid Modernity. Hoboken, NJ: John Wiley \& Sons.

Bigo, Didier. 2006. "Security, Exception, Ban and Surveillance." In Theorizing Surveillance: The Panopticon and Beyond, edited by David Lyon, 46-68. Abingdon, UK: Willan Publishing.

The Budapest Beacon. 2016. "Orbán personally ordered KEHI to investigate NGOs in 2014." Last modified October 6, 2016. http://budapestbeacon.com/featured-articles/orban-personally-ordered-kehi-to-investigate-ngos-in-2014/40423.

Bugaric, Bojan. 2015. "The Rule of Law Derailed: Lessons from the Post-Communist World.” Hague Journal of the Rule of Law 7 (2):175-97. doi:10.1007/s40803-015-0016-4.

Dubbeld, Lynsey. 2003. "Observing Bodies. Camera Surveillance and the Significance of the Body." Ethics and Information Technology 5 (3):151-62. doi:10.1023/B:ETIN.0000006946.01426.26.

Ekman, Joakim. 2009. "Political Participation and Regime Stability: A Framework for Analyzing Hybrid Regimes." International Political Science Review 30 (1):7-31. doi:10.1177/0192512108097054.

Fuchs, Christian. 2012. "Critique of the Political Economy of Web 2.0 Surveillance." In Internet and Surveillance. The Challenges of Web 2.0 and Social Media, edited by Christian Fuchs, Kees Boersma, Anders Albrechtslund, and Marisol Sandoval, 31-70. Abingdon, UK: Routledge. 
Giddens, Anthony. 1985. A Contemporary Critique of Historical Materialism: The Nation-State and Violence. Cambridge: Polity Press.

Government Control Office of the Hungarian Government. 2015. "Jogszerüen vizsgálta az Ökotársat a Kehi” (Kehi legally investigated the Ökotárs), last modified October 9, 2015. http://kehi.kormany.hu/http-gondola-hu-hirek-178543jogszeruen-vizsgalta-az-okotarsat-a-kehi-html.

Green, Stephen. 1999. "A Plague on the Panopticon: Surveillance and Power in the Global Information Economy." Information, Communication \& Society 2 (1):26-44. doi:10.1080/136911899359745.

Hadjimatheou, Kat. 2013."SURVEILLE Deliverable 4.4: Ethics and Surveillance in Authoritarian and Liberal States" (SURVEILLE. Surveillance: Ethical Issues, Legal Limitations, and Efficiency. Collaborative Project, EC $7^{\text {th }}$ Framework Programme, FP7-SEC-2011-284725). https://surveille.eui.eu/wp-content/uploads/sites/19/2015/04/D4.4-Ethics-andsurveillance-in-authoritarian-and-liberal-states.pdf.

Heathwood Institute and Press, Smith, R.C. 2013. "Authoritarianism and the NSA: Why Mass Surveillance is a Direct Product of Modern (Ideological) Society,” last modified June 9, 2013. http://www.heathwoodpress.com/authoritarianism-and-thensa-why-mass-surveillance-is-a-natural-product-of-modern-society/.

Howard, Philip N., John N. Carr, and Tema J. Milstein. 2005. "Digital Technology and the Market for Political Surveillance." Surveillance \& Society 3 (1):59-73.

Kateb, George. 2001. “On Being Watched and Known.” Social Research 68 (1):269-95. https://www.jstor.org/stable/40971451.

Kohn, Margaret. 2010. "Unblinking: Citizens and Subjects in the Age of Video Surveillance." Constellations 17 (4):572-88. doi:10.1111/j.1467-8675.2010.00615.x.

Levitsky, Steven, and Lucan A. Way. 2010. Competitive Authoritarianism: Hybrid Regimes after the Cold War. New York: Cambridge University Press.

Lyon, David, ed. 2003. Surveillance as Social Sorting: Privacy, Risk, and Digital Discrimination. Hove, UK: Psychology Press.

Lyon, David. 2007. Surveillance Studies: An Overview. Cambridge: Polity Press.

Lyon, David. 2010. "Identification, Surveillance and Democracy." In Surveillance and Democracy, edited by Kevin D. Haggerty and Minas Samatas, 34-50. New York: Routledge.

Sapsford, Roger, and Pamela Abbott. 2006. "Trust, confidence and social environment in post-communist societies." Communist and Post-Communist Studies 39 (1): 59-71.

Tavares Report. 2013. On the Situation of Fundamental Rights: Standards and Practices in Hungary (pursuant to the European Parliament Resolution of 16 February 2012) (2012/2130(INI)), (European Parliament document A7-0229/2013). http:/www.europarl.europa.eu/sides/getDoc.do?pubRef=-//EP//TEXT+REPORT+A7-20130229+0+DOC+XML+V0//EN.

Van der Burg, Wibren. 1991. “The Slippery Slope Argument.” Ethics 102 (1):42-65. doi:10.1086/293369.

Website of the Hungarian Government. 2017. "Viktor Orbán's reply in the European Parliament," last modified April $27,2017$. http:/www.kormany.hu/en/the-prime-minister/the-prime-minister-s-speeches/viktor-orban-s-reply-in-the-europeanparliament.

Žižek, Slavoj. 2010. "Liberal Multiculturalism Masks an Old Barbarism with a Human Face." The Guardian, October 3. http://www.guardian.co.uk/commentisfree/2010/oct/03/immigration-policy-roma-rightwing-europe. 